\title{
Molecular Changes Associated with Parsley and/or One Alpha Treatment of Renal Dysfunction Induced Experimentally in Rats
}

\author{
Hussein A. Abd Elmaksoud*, Omnia M. Abdel-Hamid, Afaf Desouki, Nadia R. Syam \\ Department of Biochemistry, Benha University, Egypt
}

\begin{abstract}
*Corresponding Author: Hussein A. Abd Elmaksoud, Department of Biochemistry, Benha University, Egypt.
\end{abstract}

\begin{abstract}
This study was done to investigate the ameliorative effect of Parsley extract and one-alpha on KBrO3 induced nephrotoxicity in rats. Fifty rats were classified into 5 groups: Group 1 :( normal control group): rats injected once with normal saline I/P. Group 2: (nephrotoxic group) rats injected with single dose of KBrO3 (130 mg/kg B.wt, I/P). Group 3:(parsley treated group) rats received KBrO3 then after 3 days treated with parsley extract at a dose of (400 mg/kg.b.wt /day/6 weeks) orally. Group 4 (one alpha treated group) Rats injected once with $\mathrm{KBrO} 3$ at a dose of ( $130 \mathrm{mg} / \mathrm{kg} \mathrm{B.wt,} \mathrm{I/P)}$ and after 3 days treated with one-alpha at a dose of (0. $2 \mu \mathrm{g} /$ day / 6 weeks.) orally. Group 5: (parsley extract + one alpha treated group) Rats injected once with by $\mathrm{KBrO} 3$ at a dose of $(130 \mathrm{mg} / \mathrm{kg} \mathrm{B.wt,} \mathrm{I/P)}$ and after 3 days treated with both of parsley extract

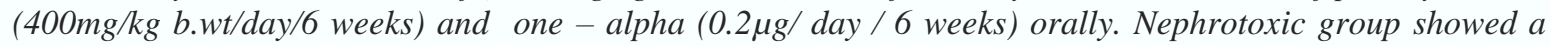
significant increase in serum creatinine activity urea and uric acid concentration when compared with normal control in addition to significant increase of renal tissue NOs, TNF- $\alpha, L-A G A T$ and caspase-3 concentration, on the other hand, serum 1- $\alpha$ hydroxlase activity showed significant decrease of nephrotoxic group in comparison to normal control. Treatment with parsley or one alpha or both revealed return of these parameters to nearly normal level. Parsley or one alpha may thus be used as a potentially promising agent to inhibit nephrotoxicity and may be a novel natural products for management of nephrotoxicity.
\end{abstract}

Abbreations: KBrO3: Pottasium Bromate, TNF-a: Tumour Necrosis Factor alpha, L-AGAT: L-Arginine: Glycine Amidinotransferase, Caspase: cysteine-aspartic proteases, NOS: nitric oxide synthase

Keywords: KBrO3, nephrotoxicity, parsley, one alpha, NOs, TNF- $\alpha, L-A G A T$.

\section{INTRODUCTION}

Kidney is an important organ within the human body. They guard blood volumes, filter the blood to form urine, regulate water, electrolytes, acid/base balance, produce some hormones and participate in metabolism of others. At rest an estimated $20 \%$ of cardiac output flows through the kidney where they are filtered and reconditioned, Nephrotoxicity is toxicity in kidneys due to poisonous effect of some substances such as toxic chemicals and medications that affect renal function by more than one way (Eman N.S, 2019).

Nephrotoxicity caused by KBrO3) Potassium bromate (seems to be attributed to the oxidative stress caused by generation of reactive oxygen species (Mahmoud et al., 2015).

The toxic effects of $\mathrm{KBrO} 3$ are attributed to its ability to induce oxidative stress (OS) leading to enhanced production of reactive oxygen species
(ROS) which are important mediators of tissue injury, The oxidative stress of potassium bromate $(\mathrm{KBrO} 3)$ induces injuries in different tissues and organs through reaction with proteins, lipids and nucleic acids. Production of reactive oxygen species (ROS) due to $\mathrm{KBrO} 3$ causes many diseases, such as cancer, ageing and diabetes mellitus, and renal cell damage (Rahmat et al., 2012) (Khan et al., 2004).

The oxidative stress induced by $\mathrm{KBrO} 3$ far exceeds the cellular antioxidative defense capacity leading to marked nephrotoxicity in humans and animals and carcinogenicity in experimental animals. Therefore, the search for safe and effective synthetic and/or naturally occurring ROS scavengers and antioxidants is of major clinical importance (Ahmad et al., 2012).

Medicinal plants and herbs play an important role in the prevention and treatment of kidney diseases. Parsley, is a bright green biennial 
shrub widely used traditionally as a food additive and herbal remedies for many ailments (Mohamad et al., 2009). It has been employed in the food, pharmaceutical, perfume, and cosmetic industries (Azab et al., 2019).

Parsley (Petroselinum crispum), which is a leafy vegetable belongs to the family Umbelliferae (Apiaceae) is known as a rich source of vitamins and minerals especially vitamins $\mathrm{C}, \mathrm{A}$ and $\mathrm{E}$; iron, calcium, phosphorus and manganese as well as many active chemical compounds. Therefore, it has many medicinal uses, the leaves are diuretic and are giving during the urinary tract infection while the fruit has a diuretic effect too in low doses but higher doses increase the contractility of the intestinal smooth muscles, bladder and uterus (Yousuf et al., 2014).

Parsley leaves are rich in Apigenin and its glucosidal flavonoids that were found to possess anti-inflammatory especially for renal inflammation; antioxidant and anticancer activities (Papay et al., 2012). In addition, the aqueous extract of parsley reduced the number of calcium oxalate deposits and therefore parsley can be used for kidney and bladder stones (Saeidi et al., 2012) (Huang et al., 2013).

Alfacalcidol $(1 \alpha(\mathrm{OH}) \mathrm{D} 3)$ is a synthetic vitamin D3 analogue, exerting full biological activity of calcitriol, it display immunomodulatory activities providing a beneficial effect in immunoinflammatory diseases, it have potent anti-inflammatory, antiproliferative, prodifferentiation and antibacterial properties in various cells and tissues (Tatjana et al., (2016).

The active D-hormone analog alfacalcidol is already hydroxylated at the crucial 1 -position. After intestinal resorption it will be automatically hydroxylated in the liver at the 25-position to become 1, 25dihydroxycholecalciferol. That means alfacalcidol is a prodrug of the D-hormone and bypasses the strongly regulated activation in the kidney. The therapeutic potential of this interesting prohormone in osteoporosis is still today often underestimated. Due to pleiotropic effects on a number of target tissues its (Ring and Schacht, 2017).

Therefore, this work aimed to evaluate using natural product as (parsley extract) alone and in combination with alfacalcidol treatment on $\mathrm{KBrO} 3$ induced nephrotoxicity in rats via estimation of molecular gene expression.

\section{MAterials ANd Methods}

\subsection{Experimental Animals}

All experiments were approved by the Ethical Committee of Faculty of Veterinary Medicine, Benha University. Fifty male Wistar albino rat $(150 \pm 20 \mathrm{~g})$ were supplied by the animal house of Faculty of Veterinary Medicine, Benha University, Egypt. They were acclimatized in our animal facility for one week under controlled environmental conditions before the experiment. Fresh daily supplies of food and tape water were served ad libitum.

\subsection{Chemicals and Antioxidant}

All chemicals were of analytical grade and obtained from standard commercial suppliers. The antioxidant and chemicals used in the present study were:

1-Potassium bromate $(\mathrm{KBrO} 3)$ was purchased from El-Gomhorya Company, Cairo, Egypt for induction of nephrotoxicity.

Dose: single dose of potassium bromate 130 $\mathrm{mg} / \mathrm{kg}$.b.wt., (Khan and Sultana, 2004).

2- One-Alpha was purchased from MINAPHARM company concentration is $(1 \mu \mathrm{g})$ capsules.

Preparation: capsule dissolved in a vehicle (medium-chain triglyceride, MCT), and diluted to a given concentration) and was given orally at. (Shiraishi et al., 2000)

Dose: $0.2 \mu \mathrm{g} / \mathrm{kg}$ b.w orally.

\section{3- Natural product (parsley):}

Preparation of aqueous parsley extract:

Freshly prepared parsley leaves extract were done at a dose of $400 \mathrm{mg} / \mathrm{kg}$ by decoction (Hemmes, 1992).

\subsection{Experimental Design}

Fifty Rats were classified into 5 groups (10 each) as follow:

- Group 1: (normal control group): normal rats injected I/P once with saline and act as control.

- Group 2: (nephrotoxoic group): Rats are injected with single dose of potassium bromate (130 mg/kg B.wt, I/P).

- Group 3: (parsley extract treated group): Rats injected once with by $\mathrm{KBrO} 3$ at a dose of $(130 \mathrm{mg} / \mathrm{kg} \mathrm{B.wt,} \mathrm{I/P})$ and after 3 days administrated parsley 
extract at a dose of $(400 \mathrm{mg} / \mathrm{kg}$ b.wt /day / 6 weeks) orally.

- Group 4: (one-alpha treated group): Rats injected once with by $\mathrm{KBrO} 3$ at a dose of $(130 \mathrm{mg} / \mathrm{kg} \mathrm{B.wt}, \mathrm{I} / \mathrm{P})$ and after 3 days treated with one-alpha at a dose of $(0.2 \mu \mathrm{g} /$ day / 6 weeks. $)$ orally.

- Group 5: (one-alpha + parsley extract treated group): Rats injected once with by $\mathrm{KBrO} 3$ at a dose of $(130 \mathrm{mg} / \mathrm{kg}$ B.wt, $\mathrm{I} / \mathrm{P})$ and after 3 days treated with parsley (400 mg/kg b.wt/day/6 weeks) and one alpha $(0.2 \mu \mathrm{g} /$ day / 6 weeks) orally.

\subsection{Sampling}

\subsubsection{Blood samples}

- Blood samples were collected twice after overnight fasting from retro- orbital plexus of eyes after 3 and 6 weeks from onset of treatment, blood samples were collected on clean tubes, then centrifugated at 2500 r.p.m for 15 minutes. Clean and sterile serum were aspirated in epindorf and kept in deep freeze till biochemical examination to check of urea (Tietz, 1976), uric acid (Zhao et al., 2006), creatinine (Henry, 1974), and 1- $\alpha$ hydroxlase Hewison, 2000.

\subsubsection{Tissue sample}

- Rats were sacrificed by cervical dislocation, stomach was opened and viscera was out then, both kidneys were isolated, washed with saline and blotted between filter papers.

- Two kidneys was preserved in a deep freezer at $80 \mathrm{c}$ in plastic bags for histopathological examination to check cytogenetics and PCR analyzes: TNF- $\alpha$ (Tumor necrosis factor), LAGAT (L-arginine -glycine amidinotransferase), caspase 3, NO synthases was measured by (Livak and Schmittgen, 2001)

\subsection{Statistical Analysis}

The results were expressed as mean \pm SE using SPSS software program version 16 (SPSS ( Inc., USA). The data were analyzed using oneway ANOVA to determine the statistical significance of differences among groups. Duncan's test was used for making a multiple comparison among the groups for testing the inter-grouping homogeneity. Values were considered statistically significant when $p<0.05$.

\section{Results}

The obtained results presented in table (1) revealed that $\mathrm{KBrO} 3$-induced nephrotoxicity in rats resulted in a significant increase of serum creatinine activity, urea and uric acid concentration. While serum 1- $\alpha$ Hydroxylase showed significant decrease when compared with normal control rats. Parsley extract treatment showed significant decrease in serum creatinine activity and non significant decrease in serum urea and uric acid concentration while non significant incease in serum 1-ahydroxylase activity. Treatment with one-alpha resulted in significant decrease in serum creatinine activity and urea concentration in comparison with nephrotoxic group

Treatment with both parsley extract and one alpha showed significant decrease of all parameters when compared with nephrotoxic group

Table1. Effect of parsley extract, one alpha or both treatment on serum urea, uric acid concentration, creatinine and 1- $\alpha$ Hydroxylase activites in $\mathrm{KBrO3-induced} \mathrm{nephrotoxicity} \mathrm{in} \mathrm{rats}$

\begin{tabular}{|c|c|c|c|c|c|c|c|c|}
\hline \multirow[t]{2}{*}{ Experimental Group } & \multicolumn{2}{|c|}{$\begin{array}{l}\text { Urea } \\
\text { (mg/dl) }\end{array}$} & \multicolumn{2}{|c|}{$\begin{array}{l}\text { Uric acid } \\
\text { (mg/dl) }\end{array}$} & \multicolumn{2}{|c|}{$\begin{array}{c}\text { Creatinine } \\
(\mathrm{mg} / \mathrm{dl})\end{array}$} & \multicolumn{2}{|c|}{$\begin{array}{c}\text { 1- } \alpha \text { Hydroxylase } \\
(\mathrm{pg} / \mathrm{mL})\end{array}$} \\
\hline & 3 Weeks & 6 Weeks & 3 Weeks & 6 Weeks & 3 Weeks & 6 Weeks & 3 Weeks & 6 Weeks \\
\hline Control group & $\begin{array}{c}17.05 \pm \\
1.56^{\mathrm{c}}\end{array}$ & $\begin{array}{r}18.94 \pm \\
1.73^{\mathrm{c}}\end{array}$ & $\begin{array}{l}1.74 \pm \\
0.34^{\mathrm{c}}\end{array}$ & $\begin{array}{l}1.64 \pm \\
0.32^{\mathrm{b}}\end{array}$ & $\begin{array}{l}1.02 \pm \\
0.22^{\mathrm{b}} \\
\end{array}$ & $\begin{array}{c}0.95 \pm \\
0.20^{\mathrm{b}}\end{array}$ & $\begin{array}{c}62.45 \pm \\
3.18^{\mathrm{a}}\end{array}$ & $\begin{array}{c}56.78 \pm \\
2.90^{\mathrm{a}}\end{array}$ \\
\hline Nephrotoxic group & $\begin{array}{c}63.60 \pm \\
7.30^{\mathrm{a}}\end{array}$ & $\begin{array}{c}53.00 \pm \\
6.08^{\mathrm{a}}\end{array}$ & $\begin{array}{l}4.15 \pm \\
0.69^{\mathrm{a}}\end{array}$ & $\begin{array}{l}3.46 \pm \\
0.58^{\mathrm{a}}\end{array}$ & $\begin{array}{l}5.80 \pm \\
1.65^{\mathrm{a}}\end{array}$ & $\begin{array}{l}4.97 \pm \\
1.41^{\mathrm{a}}\end{array}$ & $\begin{array}{l}20.80 \pm \\
3.95^{\mathrm{b}}\end{array}$ & $\begin{array}{r}26.00 \pm \\
4.93^{c}\end{array}$ \\
\hline $\begin{array}{l}\text { Parsley e } \\
\text { group }\end{array}$ & $\begin{array}{l}47.10 \pm \\
6.24^{\mathrm{ab}}\end{array}$ & $\begin{array}{l}39.25 \pm \\
5.20^{\mathrm{ab}}\end{array}$ & $\begin{array}{l}3.22 \pm \\
0.28^{\mathrm{ab}}\end{array}$ & $\begin{array}{l}2.68 \pm \\
0.23^{\mathrm{ab}}\end{array}$ & $\begin{array}{l}2.03 \pm \\
0.41^{b}\end{array}$ & $\begin{array}{l}1.74 \pm \\
0.35^{\mathrm{b}}\end{array}$ & $\begin{array}{l}24.25 \pm \\
2.55^{\mathrm{b}}\end{array}$ & $\begin{array}{l}30.31 \pm \\
3.18^{\mathrm{bc}}\end{array}$ \\
\hline One alpha treated group & $\begin{array}{l}41.03 \pm \\
3.47^{\mathrm{b}}\end{array}$ & $\begin{array}{l}34.19 \pm \\
2.89^{\mathrm{b}}\end{array}$ & $\begin{array}{l}3.08 \pm \\
0.31^{\mathrm{ab}}\end{array}$ & $\begin{array}{l}2.56 \pm \\
0.26^{\mathrm{ab}}\end{array}$ & $\begin{array}{l}2.01 \pm \\
0.37^{\mathrm{b}}\end{array}$ & $\begin{array}{l}1.73 \pm \\
0.32^{b}\end{array}$ & $\begin{array}{l}23.69 \pm \\
2.54^{\mathrm{b}}\end{array}$ & $\begin{array}{l}29.61 \pm \\
3.18^{\mathrm{bc}}\end{array}$ \\
\hline $\begin{array}{l}\text { Parsley extract + One } \\
\text { alpha treated group }\end{array}$ & $\begin{array}{c}34.93 \pm \\
6.24^{\mathrm{b}}\end{array}$ & $\begin{array}{l}29.11 \pm \\
5.20^{\mathrm{b}}\end{array}$ & $\begin{array}{l}1.97 \pm \\
0.38^{\mathrm{bc}}\end{array}$ & $\begin{array}{l}1.64 \pm \\
0.32^{b}\end{array}$ & $\begin{array}{l}1.47 \pm \\
0.24^{\mathrm{b}}\end{array}$ & $\begin{array}{l}1.26 \pm \\
0.20^{\mathrm{b}}\end{array}$ & $\begin{array}{l}32.05 \pm \\
4.40^{\mathrm{b}}\end{array}$ & $\begin{array}{c}40.06 \pm \\
5.50^{\mathrm{b}}\end{array}$ \\
\hline
\end{tabular}

Data are presented as (Mean \pm S.E). S.E $=$ Standard error.

Mean values with different superscript letters in the same column are significantly different at $(P<0.05)$. 
The obtained results presented in table (2) revealed a significant up regulation of renal tissue TNF- $\alpha$, L-AGAT, Caspase- 3 , NOS gene expression of $\mathrm{KBrO} 3$-induced nephrotoxicity in rats when compared with normal control rats. Treatment with parsley extract or one alpha or their combination revealed non significant down regulation of renal TNF- $\alpha$ and renal L-AGAT when compared with nephrotoxic group.

Combination treatment of parsley extract and one - alpha showed significant down regulation of L-AGAT, renal caspase 3 and NOS when compared with nephrotoxic group

Table2. Effect of parsley, one alpha or both treatments on renal tissue TNF- $\alpha, L-A G A T$, Caspase-3, NOS gene expression in $\mathrm{KBrO3}$-induced nephrotoxicity in rats

\begin{tabular}{|c|c|c|c|c|c|}
\hline \multirow[t]{2}{*}{ Experimental Group } & \multirow{2}{*}{$\begin{array}{c}\text { Renal TNF- } \alpha \\
\text { gene } \\
\text { expression }\end{array}$} & \multirow{2}{*}{$\begin{array}{l}\text { Renal L- } \\
\text { AGAT gene } \\
\text { expression }\end{array}$} & \multirow{2}{*}{$\begin{array}{c}\text { Renal Caspase-3 } \\
\text { Immunohisto- } \\
\text { chemical expression }\end{array}$} & \multicolumn{2}{|c|}{ NOS (ng/mL) } \\
\hline & & & & 3 Weeks & 6 Weeks \\
\hline Control group & $1.15 \pm 0.09^{b}$ & $6.47 \pm 1.44^{b}$ & $0.06 \pm 0.01^{b}$ & $60.13 \pm 2.40^{\mathrm{d}}$ & $54.67 \pm 2.19^{d}$ \\
\hline Nephrotox & $1.89 \pm 0.29^{\mathrm{a}}$ & $16.97 \pm 2.89^{\mathrm{a}}$ & $0.17 \pm 0.03^{a}$ & $108.50 \pm 2.26^{\mathrm{a}}$ & $98.64 \pm 2.05^{\mathrm{a}}$ \\
\hline $\begin{array}{l}\text { Parsley extract treated } \\
\text { group }\end{array}$ & $1.59 \pm 0.12^{\mathrm{ab}}$ & $11.53 \pm 2.02^{\mathrm{ab}}$ & $0.11 \pm 0.01^{\mathrm{ab}}$ & $90.50 \pm 4.14^{b}$ & $82.28 \pm 3.77^{b}$ \\
\hline One alpha treated grou & $1.51 \pm 0.16^{\mathrm{ab}}$ & $11.56 \pm 2.02^{\mathrm{ab}}$ & $0.11 \pm 0.02^{\mathrm{ab}}$ & $74.65 \pm 1.41^{\mathrm{c}}$ & $67.86 \pm 1.28^{\mathrm{c}}$ \\
\hline $\begin{array}{l}\text { Parsley extract + One } \\
\text { alpha treated group }\end{array}$ & $1.31 \pm 0.12^{\mathrm{ab}}$ & $8.72 \pm 2.03^{b}$ & $0.09 \pm 0.02^{b}$ & $69.82 \pm 1.37^{c}$ & $63.47 \pm 1.25^{\mathrm{c}}$ \\
\hline
\end{tabular}

\section{DISCUSSION}

Kidney dysfunction is becoming a major public health problem. Previous investigation has shown that acute renal injury and chronic kidney disease are major contributory factors to mortality and morbidity in many developing countries (Xu et al., 2018). Some of the pathological conditions associated with renal dysfunction include acute kidney injury (AKI), chronic kidney disease (CKD), nephrotoxicity, renal hypoxia, and ischemic reperfusion injury. Several factors may be responsible for the development and progression of renal disease/dysfunction. Degenerative diseases such as cardiovascular disease, diabetes mellitus, hypertension, and dyslipidemia have been highlighted as causative factors of renal dysfunction (Dennis and Witting, 2017).

The obtained results presented in table (1) revealed a significant increase of serum urea, uric acid concentration and, creatinine activity. On the other hand serum 1- $\alpha$ Hydroxylase was significant decrease in $\mathrm{KBrO} 3$-induced nephrotoxicity in rats. These results are nearly similar to those reported by of (Rezq, 2017) who mentioned that, injection of $\mathrm{KBrO} 3$ resulted in a significant elevation in serum level of Urea, Uric acid concentration and creatinine activity which reflect the functional status of the kidneys, and detect diseases that affect the kidneys, such as acute kidney failure or endstage renal disease (ESRD), this may be due to the toxic effect of potassium bromate that lead to renal failure. Furthermore, (Afaf et al., 2008) discussed that, increased blood Urea, creatinine activity and Uric acid concentration are strongly related with renal damage.

(Ali et al., 2018) reported that, Treatment of rats with $\mathrm{KBrO} 3$, significantly raised creatinine concentration. In addition, (Khan et al., 2012) found that, High levels of urobilinogen, urea, creatinine, protein and albumin in urine reflect the kidney dysfunction and renal injuries induced by $\mathrm{KBrO} 3$ treatment (Ogeturk et al., 2005).

Moreover, (Ahmad et al., 2013) found that, Administration of $\mathrm{KBrO} 3$ alone to rats produced a typical pattern of nephrotoxicity which was manifested by several fold increase in creatinine and BUN levels, as also reported previously (Ahmad et al. 2012).

Treatment with parsley extract to $\mathrm{KBrO} 3$ induced nephrotoxicity in rats caused decrease in creatinine activity, urea and uric acid concentration. On the other hand increase in serum 1- $\alpha$ Hydroxylase of $\mathrm{KBrO} 3$-induced nephrotoxicity in rats. These results confirmed by (Ayman et al., 2015) who found that, treatment with parsley extract showed a significant decreased in serum blood creatinine activity and urea, and uric acid concentration because parsley has a significant effect in improvement of renal disorders by reduction of generation of uremic toxins and aggregation with pathogenic bacteria.

Also, (Abeer, 2015) reported that, the oral ingestion of parsley extract has significantly reduced the pathologic concentration of various marker molecules of CKD by a way of probably 
altering the composition of colon microbiota and generation uremic toxins. Thus, parsley extract serve as dietary supplement to maintain a natural metabolic and physiological renal mechanism and so it reduced nephrotoxicity. Furthermore, (Khalil et al., 2015) revealed that, in an animal study- that, urea level, creatinine and uric acid levels were found to be significantly lowered by peppermint and parsley leaves oils supplementation with the same trend that recorded insignificant in these parameters. Also, (Dhanarasu et al., 2016) reported that, The gentamicin induced neprotoxicity were confirmed by an increase in serum creatinine, uric acid, urea and blood urea nitrogen levels and severe proximal renal tubular necrosis, followed by deterioration and renal failure then these parameters were almost significantly normalized by oral administered parsley.crispum extracts and parsley.crispum leaves Decoction (groups III and IV) animals. This result is consistent with many previous studies done using other traditional plants (EIAdawi et al., 2011).

Treatment with one-alpha to $\mathrm{KBrO} 3$ induced nephrotoxicity in rats caused decrease in creatinine, urea, uric acid. On the other hand increase in serum 1- $\alpha$ Hydroxylase of $\mathrm{KBrO} 3-$ induced nephrotoxicity in rats. Our results agree with (Shoben et al., 2008) who found that, treatment with alfacalcidol showed a significant decreased in serum blood urea, creatinine and uric acid and showed improvement of renal disorders. Also, (Marianne et al., 2004) reported that, serum urea, creatinine, and uric acid values did not change and even tended to decrease. Glomerular filtration was found to increase insignificantly more markedly in the patients with renal failure in the early stages because alfacalcidol normalizes metabolic process and promotes recycling product exchange so it reduced nephrotoxicity. Alfacalcidol (1 a-hydroxy vitamin D3), a synthetic analogue of vitamin D, Alfacalcidol is hydroxylated in the liver to calcitriol $(1,25$ dihydroxyvitamin D) and has a stable pharmacokinetic profile as it avoids serum peaks that may lead to elevated calcium levels and associated adverse effects (Sachiyo et al., 2010).

The obtained results presented in table (2) revealed a significant up regulation in both increase of renal tissue Caspase-3, TNF- $\alpha$, L-
AGAT, NOS gene expression were observed after injection of potassium bromate.

These results agree with (Rehman et al., 2012) who showed, up regulation in caspase-3 gene expression after injected of $\mathrm{KBrO}$. Increased ROS levels contribute to the apoptotic cell death every time they are generated in the context of the apoptotic process (Liu et al., 2010). Caspase- 3 is one of the key executioners of apoptosis, as it can be activated in both intrinsic and extrinsic pathway. Activated caspase- 3 has the potential of cleaving or degrading many key proteins such as fodrin, nuclear lamins and the nuclear enzyme poly (ADP ribose) polymerase (PARP).Also, (Rehman et al., 2012) demonstrated that Caspase-3 activity was significantly up-regulated in $\mathrm{KBrO} 3$ treated group and pretreatment with B.monnieri significantly restored the Caspase-3 activity.

Furthermore, (Ben Saad et al., 2018) found that, a concomitant significant increase in TNF- $\alpha$ and IL-6 mRNA in the cerebellum of $\mathrm{KBrO} 3$-treated mice. Cell surface death receptors transmit apoptotic signals initiated by specific ligands, such as Fas, TNF- $\alpha$, and other related ligands which activate a caspase cascade.

Moreever, (Ben Saad et al., 2018) investigated that, TNF- $\alpha$ mRNA increased after $\mathrm{KBrO} 3$ treatment. Also, (Ben Saad et al., 2018) suggested that, $\mathrm{KBrO} 3$ induces oxidative stress in the cerebellum and causes lipid peroxidation, leading to a disruption of the cell membrane, loss of ATPase activity, decrease in antioxidant enzyme activity, and increase in inflammatory cytokine expression. Many studies have revealed oxidative stress to be the major cause of the inflammation stimulating the release of several proinflammatory cytokines. Redox status has also been shown to influence NF-kB regulation and hence several genes involved in cell transformation, proliferation, and angiogenesis. Although, relationship between ROS and NF-kB is complex, ROS are believed to be implicated as second messengers in the activation of NF-kB via TNF-a and other proinflammatory cytokines (Reuter et al., 2010)

On the other hand, (Memmedov et al., 2020) reported that, potassium bromate caused a decrease in caspase-3, caspase-8, caspase-9, cytochrome-c, TRAIL, and APAF levels in CCD 841 normal colon cells.

Amidinotransferase (transamidinase, L-arginine: glycine amidinotransferase, is an enzyme that 
catalyses the first step in creatine synthesis primarily in the kidney and pancreas. The kidney is also the primary target organ for the toxic effect of potassium bromate (Jelenka and Dusan, 2004).

Treatment with parsley extract or Alfacalcidol or both to $\mathrm{KBrO} 3$ - induced nephrotoxicity in rats caused, non significant down regulation in both Caspase-3,TNF- $\alpha$, L-AGAT, NOS gene expression when compared with $\mathrm{KBrO} 3$ induced nephrotoxicity non treated group.

These results are recorded with (Takrooni $\boldsymbol{e t}$ al., 2019) who reported that, Co-administration of parsley leaves extract with CsA ameliorate the level of 8-OHdG and caspase-3. It could be stated that parsley leaves extract provided a significant protection against CsA-induced renal DNA damage and apoptosis. This outcome was in agreement with (Sharma et al. 2014) who found that plant flavone apigenin (main constituent of parsley) binds to nucleic acid bases and decrease oxidative DNA damage in prostate epithelial cells. This finding supports that parsley suppressed the DNA damage and have an anti-apoptotic role in kidney cells. This property helps to prevent kidney from free radical stress. Cell death is the final phase of cellular damage; it happens by apoptosis. Caspases are cysteine-aspartyl proteases which play an important role in apoptosis. Caspase-3, in particular, is the most important effector of caspases widely studied (Pandurangan $\boldsymbol{e t}$ al., 2014). These results were in agreement with $\mathrm{Wu}$ et al (2018) who study the mechanism of Cyclosporin A nephrotoxicity. As CsA increase the level of NF- $\kappa B$ and TNF- $\alpha$, these increases were attenuated by treatment with parsley leaves extract. These results suggest that the parsley leaves extract modulates the expressions of NF$\kappa \mathrm{B}$ and TNF- $\alpha$; the results are in agreement with (Malik et al. 2017). Using apigenin essentially reduce the levels of TNF- $\alpha$, IL-1 $\beta$, and TGF $\beta$ in rat's kidneys. Moreover, apigenin inhibited the activations of CYP2E1, phosphoNF- $\kappa$ B p65 and phospho-P38 MAPK in cisplatin-induced renal damage (He et al., 2016). Apigenin belongs to the flavone subclass of flavonoids and is abundant in parsley leaves extract, which confirm the anti-inflammatory effect of Parsley leaves extract.

\section{CONCLUSION}

The obtained results suggested that treatment with parsley extract or/and one-alpha led to improvment of renal cells functions and can reduce the nephrotoxic effect of pot. bromate which revealed by apparent reduction in serum creatinine activity, urea, uric acid, renal tissue Caspase-3, TNF- $\alpha$, L-AGAT, NOS gene expression. On the other hand elevate in serum1- $\alpha$ Hydroxylase level. It could be concluded with using both combination of parsley extract as a cofactor with one alpha in treatment of renal dysfunction.

\section{REFERENCES}

Abeer E. Elkhamisy, (2015): Protective Effect of Parsley Leaves and Turmeric Roots Extracts Against Gentamicin Induced Nephrotoxicity in Male Rats; World Journal of Dairy \& Food Sciences 10 (1): 01-08.

Adewole SO, Salako AA, Doherty OW, Naicker T, (2007): Effect of melatonin on carbon tetrachloride-induced kidney injury in Wistar rats. African J Biomed Res, 10:153164.

Afaf I. Abuelgasim, Rehab Omer and B. Elmahdi, (2008): Serrobiochemical Effects of Potassium Bromate on Wistar Albino Rats. American Journal of Food Technology, 3: 303-309.

Ahmad MK, Khan AA, Mahmood R. (2013): Taurine ameliorates potassium bromateinduced kidney damage in rats. Amino Acids. ;45:1109-1121.

Ahmad MK, Naqshbandi A, Fareed M, Mahmood $R$ (2012): Oral administration of a nephrotoxic dose of potassium bromate, a food additive, alters renal redox and metabolic status and inhibits brush border membrane enzymes in rats. Food Chem 134:980-985.

Ahmed, M.K. and Mahmood, R . (2012) : Oral administration of potassium bromate, amajor water disinfection byproduct, induces oxidative stress and impairs the antioxidant power of rat blood. Chemosphere . 87(7): 750-756.

Ali, B. H., Za'abi, M. A., Karaca, T., Suleimani, Y. A., Balushi, K., Manoj, P., Ashique, M., ... Nemmar, A. (2018). Potassium bromate-induced kidney damage in rats and the effect of gum acacia thereon. American journal of translational research, 10(1), 126-137.

Ayman F. Khalil a, Haiam O. Elkatry a,*, Hanaa F. El Mehairy b, (2015): Protective effect of peppermint and parsley leaves oils against hepatotoxicity on experimental rats; Annals of Agricultural Science, 60 (2): 353359. 
Azab E. A., Fikry A. A., Halima M. A. Abdul R. (2019): Nephroprotective Effect of Aqueous Extract of Parsley against Nephrotoxicity Induced by Carbon Tetrachloride in the Male Rats; Journal of Biotechnology and Bioengineering ,3, (4) : 16-26.

Ben Saad H, Dorra D, Imen J, Hanen G, Ons B, Michael D, Christian M, Monsef N, Khaled M Z, Ahmed H, I Ben Amara. (2018): Potassium Bromate-induced Changes in the Adult Mouse Cerebellum Are Ameliorated by Vanillin. Biomedical and Environmental Sciences, 31(2): 115125.

Dennis JM, Witting PK (2017): Protective role for antioxidants in acute kidney disease. Nutrients 9(7).

Dhanarasu S, Ahmad, Abdullah \& Saleh, Abdulrahman \& Alrusayni, Albaraa \& Khalid, Abdulkarim \& Aloraifi, Omar \& - (2016): Efficacy of parsley (Petroselinum crispum) leaves extract and decoction on status of lipid profile and osmotic fragility in gentamicin-induced nephrotoxicity in rats. Journal of Chemical and Pharmaceutical Research. 8. 948-957.

El-Adawi H, El-Azhary D, Abd El-Wahab A, ElShafeey M, Abdel-Mohsen M. (2011): J Med Plant Res, 2011, 5(27): 6316-6327.

Eman N.S, (2019): Biochemical effects of probiotic administration on renal disorders. Benha university, Faculty of Veterinary medicine, biochemistry department.15-25.

Giri U, Iqbal M, Athar M (1999): Potassium bromate $(\mathrm{KBrO} 3)$ induces renal proliferative response and damage by elaborating oxidative stress. Cancer Lett 135:181-188.

He, X., et al., (2016): Protective role of apigenin in cisplatin-induced renal injury. European Journal of Pharmacology, 2016. 789: p. 215-221.

Hemmes, Helde, (1992): Herbs. Edited by Andrew Tobin, Published by South Australian School of Herbal Medicine, Ridge haven, South Australia.

Henry T.J. 2th ed: Harper and Row Publishers; New York: 1974. Clinical Chemistry Principles and Techniques.

Hewison, M. (2000): 1alpha-Hydroxylase and the action of vitamin D. Journal of Molecular Endocrinology. $25 . \quad 141-148$. 10.1677/jme.0.0250141.

Huang, J., K. Huang, T. Lan, X. Xie, X. Shen, P. Liu and H. Huang, (2013): Curcumin ameliorates diabetic nephropathy by inhibiting the activation of the SphK1S1P signaling pathway. Molecular Cell Endocrinology, 365(2): 231-240.
Jelenka N \& Dusan S, (2004): Lespeflan, a Bioflavonoid, anAmidinotransferase Interaction in Mercury Chloride Intoxication Renal Failure, 26:6, 607-611.

Khalil AF, Elkatry HO, El Mehairy HF. (2015): Protective effect of peppermint and parsley leaves oils against hepatotoxicity on experimental rats. Annals of Agricultural Science (2015) 60(2), 353-359.

Khan N, and Sultana S (2004): Abrogations potassium bromate- induced renal oxidative stress and subsequent cell proliferation response by soy isoflavones in wistar rats. Toxicology 201(1-3):173-184.

Khan, N., Sharma,S. and Sultana, S., (2004): Attenuation of potassium bromate-induced nephrotoxicity by coumarin (1,2benzopyrone) in Wistar rats: chemoprevention against free radicalmediated renal oxidative stress and tumor promotion response; Redox Report, Vol. 9, No. 1.

Khan RA, Khan MR, Sahreen S.(2012): Protective effects of rutin against potassium bromate induced nephrotoxicity in rats. BMC Complement Altern Med.;12: 204.

Liu CM, Zheng YL, Lu J, Zhang ZF, Fan SH, Wu DM, Ma JQ. (2010): Quercetin protects rat liver against lead-induced oxidative stress and apoptosis. Environ. Toxicol. Pharmacol, 29, 158-166.

Livak, K.J. and Schmittgen, T.D. (2001): Analysis of relative gene expression data using realtime quantitative PCR and the $2(-\Delta \Delta \mathrm{Ct})$ method. Methods. ;25:402-408.

Mahmoud N.Y., Salem Z. A. and El-Moslemany A. M. (2015): Nephroprotective and Antioxidant Effects of Parsley Plant Parts Against Gentamicin-Induced Nephrotoxicity in Rats; Academic Journal of Nutrition 4 (3): 113-122.

Malik, S., et al., (2017): Apigenin ameliorates streptozotocin-induced diabetic nephropathy in rats via MAPK-NFB-TNF- and TGF- 1MAPK-fibronectin pathways. Am J Physiol Renal Physiol 313: p. F414-F422.

Marianne Rix, Peter Eskildsen, Klaus Olgaard, (2004): Effect of 18 months of treatment with alfacalcidol on bone in patients with mild to moderate chronic renal failure Nephrology Dialysis Transplantation, Volume 19 (4):870-876.

Memmedov, H, Oktay, LM, Durmaz, B, Günel, NS, Yildırım, HK, Sözmen, EY. (2020): Propolis prevents inhibition of apoptosis by potassium bromate in CCD 841 human colon cell. Cell Biochem Funct. 2020; 38: 510- 519. 
Mohamad, R.H., A.M. El-Bastawesy, Z.K. Zekry, H.A. Al-Mehdar and M.M. Merzabani, (2009): The role of Curcuma longa against doxorubicin (Adriamycin) induced toxicity in rats. Journal of Medicinal Food, 12(2): 394-402.

Moore EM, Bellomo R, and Nichol AD (2012): The meaning of acute kidney injury and its relevance to intensive care and anaesthesia. Anaesthesia and intensive care 40:929-948.

Ogeturk M, Kus I, Colakoglu N, Zararsiz I, Ilhan N, Sarsilmaz M (2005): Caffeic acid phenyl ester protects kidney against carbon tetrachloride toxicity in rats. J Ethnopharmcol 2005, 97:273-280.

Ozturk F, Ucar M, Ozturk IC, Vardi N, Batcioglu K. (2003): Carbon tetrachloride induced nephrotoxicity and protective effect of betaine in Sprague dawley rats. Urology 2003, 62:353-356.

Pandurangan, A.K. and N.M. (2014): Esa Luteolin, a bioflavonoid inhibits colorectal cancer through modulation of multiple signaling pathways: A review. Asian Pac J Cancer Prev, 15(14): p. 5501-5508.

Papay, Z.F., A. Kosa, I. Boldizsar, A. Ruszkai, E. Balogh and I. Antal, (2012): Pharmaceutical and formulation aspects of Acta Pharmaceutica Hungarica, 82(1): 3-14. Petroselinum crispum extract.

Rahmat A, K, Muhamad R, K, and Sumaira S, (2012): Protective effects of rutin against potassium bromate induced nephrotoxicity in rats: Complementary and Alternative Medicine ,12:204.

Rehman, M \& Tahir, M \& Khan, A \& Lateef, M \& Khan, $R$ \& Hamiza, O \& Qamar, W \& Kazim, S \& Ali, F \& Sultana, S. (2012): Methanolic extract of Bacopa monnieri protects against $\mathrm{KBrO} 3$-induced renal damage in Wistar rats by restoring antioxidant enzyme activities and suppressing inflammation and apoptosis. The Journal of Pharmacy.

Reuter S, Gupta SC, Chaturvedi MM, Aggarwal BB. (2010): Oxidative stress, inflammation, and cancer: How are they linked? Free Radical Biology \& Medicine. 49, 16031616.

Rezq, A. (2017). Potential Protective and Ameliorate Effects of Sesame Oil and Jojoba Oil Against Potassium Bromate (KBrO3)induced oxidative stress in rats. 3. 1 .

Richy F. Rita Deroisy R., Lecart M.P., Hanssens L., Mawet A., and Reginster J.Y.(2005): D-Hormone analog alfacalcidol an update on its role in post-menopausal osteoporosis and rheumatoid arthritis management: Aging Clin Exp Res, (17),. 2: 133.
Ringe J. D. and Schacht E, ( 2007): Improving the outcome of established therapies for osteoporosis by adding the active Dhormone analog alfacalcidol; Rheumatol Int $.28: 103-111$.

Sachiyo S, Daijo I, Akimitsu K, Minako M, Yutaka K, Sho S, Kyoko H, Hiroshi N, Miho T, Kei K, Yukio Y, Seiichi M, (2010): Administration of alfacalcidol for patients with predialysis chronic kidney disease may reduce cardiovascular disease events: Clin Exp Nephrol, 14:43-50.

Saeidi, J.,m H. Bozorgi, A. Zendehdel and J. Mehrzad, (2012): Therapeutic effects of aqueous extracts of Petroselinum sativum on ethylene glycol-induced kidney calculi in rats. Urology Journal, 9(1): 361-366.

Sharma, H., et al., (2014): Plant flavone apigenin binds to nucleic acid bases and reduces oxidative DNA damage in prostate epithelial cells. PLoS One, 2014. 9(3): p. e91588.

Shiraishi, A., Takeda, S., Masaki, T., Higuchi, Y., Uchiyama, Y., Kubodera, N., Sato, K., Ikeda, K., Nakamura, T., Matsumoto, T. and Ogata, E. (2000): Alfacalcidol Inhibits Bone Resorption and Stimulates Formation in an Ovariectomized Rat Model of Osteoporosis: Distinct Actions from Estrogen. J Bone Miner Res, 15: 770-779.

Shoben AB, Rudser KD, de Boer IH, Young B, Kestenbaum B 2008: Association of oral calcitriol with improved survival in nondialyzed CKD. J Am Soc Nephrol;19:1613-9.

Takrooni, W. A.,. Sharaf I. A, N. A. Abdul Majid, (2019): Assessment of The Potential Role of Parsley (Petroselinum Crispum) Leaves Extract in Ameliorating Cyclosporin AInduced Nephrotoxicity in Rats. Int.J. Pharm. Res. Allied Sci., 8(2):118-128.

Tatjana Ž,R, Katarina S,P, Mirjana S, B, Sonja M, D, Andelk, I,T, Stojkovic, N, P, Nemanja, D, and Jelen V, (2016): Alfacalcidol modulates oxidative stress parameters in the peripheral blood of patients with active rheumatoid arthritis; J. Serb. Chem. Soc. 81 (10) 1127-1139 .

Tietz, N. (1976): Fundamentals of clinical chemistry. Philadelphia: W. B. Saunders.

Wu, Q., et al., (2018): Mechanism of cyclosporine A nephrotoxicity: Oxidative stress, autophagy, and signalings. Food and Chemical Toxicology,. 118: p. 889-907.

Xu X, Nie S, Ding H, Hou FF. (2018): Environmental pollution and kidney diseases. Nat Rev Nephrol 14(5):313-324. 
Yousuf H. A., Al-Zubaidi F.S., Yousif W.H., (2014): Study of the Interaction Effect Between Parsley Petroselinum crispum and Cadmium on Lipid Profile, Lipid Peroxidation and Catalase Activity of Albino Mice Males' Liver and Kidney; Iraqi Journal of Science; 55, (2B) 711-721.
Zhao Y, Zhao L, Yang G, Tao J, Bu Y, Liao F. (2006): Characterization of a uricase from Bacillus fastidious A.T.C.C. 26904 and its application to serum uric acid assay by a patented kinetic uricase method. Biotechnol Appl Biochem. 2006;45(Pt 2):75-80.

Citation: Hussein A. Abd Elmaksoud, Omnia M. Abdel-Hamid, Afaf Desouki, Nadia R. Syam. Molecular Changes Associated with Parsley and/or One Alpha Treatment of Renal Dysfunction Induced Experimentally in Rats. ARC Journal of Nutrition and Growth. 2020; 6(2):19-23. DOI: https://doi.org/10.20431/24552550.0602004 .

Copyright: (C) 2020 Authors. This is an open-access article distributed under the terms of the Creative Commons Attribution License, which permits unrestricted use, distribution, and reproduction in any medium, provided the original author and source are credited. 